\title{
EFFECT OF NATURE CONSERVATION ON THE SOCIO-ECONOMIC DEVELOPMENT OF MUNICIPALITIES IN THE SOUTH WESTERN BORDER REGION OF THE CZECH REPUBLIC
}

\author{
KAROLÍNA BÍLÁ1,*, ZDENKA K ǨENOVÁ ${ }^{1,2}$, ZDENĚK PÍCHA², \\ and PAVEL KINDLMANN ${ }^{1,2}$

\footnotetext{
${ }^{1}$ Department of Biodiversity Research, Global Change Research Institute CAS, Bělidla 986/4a, 60300 Brno, Czech Republic

2 Institute of Environmental Studies, Charles University, Benátská 2, 12801 Prague 2, Czech Republic

*Corresponding author: kcerna@volny.cz
}

\begin{abstract}
In this study, we focus on factors affecting the socio-economic development within a protected zone and attempt to elucidate if being in a protected area significantly affects the development or whether other factors also have a role. We focused on population counts recorded in 1991 and 2011 in order to identify the changes in the economy following to the establishment of the Šumava National Park in 1991 and Český les Protected Landscape Area (PLA) in 2005. A total of 39 municipalities of similar size and history were included and 18 socio-economic indicators, which can be broadly categorized in terms of economy, landscape use and municipality income. We performed ANCOVA to determine the association between the size and location (outside or inside protected area) of a municipality and each of the 18 socio-economic indicators. They did not vary significantly in 1991. After two decades the demography, economy and landscape usage were significantly different. However, they were not a result of being in a protected area but changes in the sizes of the municipalities. The municipalities located within protected areas may profit from their locality and it has positive rather than negative effects on the socioeconomic indicators.
\end{abstract}

Keywords: border region; Český les PLA; demography; protected area; socio-economic development; Šumava NP

\section{Introduction}

One of the most important achievements of nature conservation is protection, implemented by means of specially protected areas, such as national parks (NP) or protected landscape areas (PLA). In the Czech Republic, these protected areas are proclaimed under Act no. 114/1992 Coll. on Nature and Landscape Protection of sites of scientific or aesthetic importance or uniqueness. Such sites are protected because of their biological diversity, unique geology or are typical elements of a particular landscape. The reason for protecting a site is to conserve or improve its preserved state or leave it to spontaneous development.

In the Czech Republic there are no unpopulated landscapes, which imply some restrictions on socio-economic development of municipalities located in protected areas, such as, agriculture practices, building new roads or railways, location of industrial buildings, mining, etc. The management of such areas must take into account the level of protection of the areas in which they are located in order to preserve and create optimum ecological conditions and provide the inhabitants with a good living. Recreational use should be allowed provided it does not adversely affect the natural values of the protected area. Currently, people living in protected territories want to change the legislation and so reduce the level of protection of zones with built-up areas. The strongest argument of the protesters is the incorporation of their municipalities into the Šumava National Park has resulted in a decrease in their socio-economic development.
In this study, we focus on the factors affecting the socio-economic development within a protected zone and attempt to elucidate if being in a protected area significantly affects the development or whether other factors have a crucial role. We focused on population counts recorded in the years 1991 and 2011 in order to identify changes in the economy due to the establishment of the Šumava National Park in 1991.

\section{Methods}

\section{Study area}

The study area is located on the south-western border of the Czech Republic (Fig. 1) and extends from the northern border of the Český les PLA, across the Šumava $\mathrm{NP}$ and PLA, to the eastern border of the future and not yet proclaimed Novohradské hory PLA, which was recently protected by being designated a natural park. There are also many smaller protected areas located here, for example, the national nature reserve (NNR) Terčino údolí, national natural monument (NNM) Hojná voda, Žofínský prales NNR, Čertova stěna-Luč (NNR) andNATURA 2000 network: special protection areas (SPA) designated for birds Boletice, Novohradské hory, Šumava and many sites of community importance (SCI) designated for habitats, plant and animal species. The study area belongs to the following municipalities: České Budějovice, Český Krumlov, Domažlice, Klatovy, Prachatice and Tachov (Albrecht et al. 2003; Zahradnický and 
Mackovčin 2004). From the historical point of view, the study area is in the Sudetes or more specifically the Poor Sudetes (Perlín 1998).

Climate in this region varies depending on altitude with decreasing mean temperature and increasing precipitation from $900 \mathrm{~mm}$ to $1,600 \mathrm{~mm}$ (Albrecht et al. 2003; Křivancová et al. 2006; Bílá et al. 2018).

Vegetation cover in this area is dense forest of beech mixed with fir at low altitudes and spruce forests in the high mountains along with growths of ash-alder and peat bogs at waterlogged localities, mountain grassland and pastures characteristic of the Šumava NP. At the lowest altitudes in the Český les PLA there are also oak forests (Sofron 1990). There are a number of protected species in the area, but the most valuable are ecosystems unaffected by human activities (Albrecht et al. 2003; Zahradnický and Mackovčin 2004).

\section{Settlement history}

The very first human settlements were in the 7 th and 8th century when Slavic folk inhabited sites along streams. Population density increased during the Middle Ages and both Czech and German cultures occurred in the study area, whereas Germans prevailed in the central part of the Šumava and Czechs settled more in the Šumava foothills (Nikrmajer 2003; Řezníčková 2003, 2005, 2006; Matušková 2005a; Sassmann 2006).

There were marked changes in 1918 when Czechoslovakia was established and Czechs were moved to sites on the south-western border. In 1938, most of the area studied belonged to Germany but after the Second World War in 1945, Germans had to leave this locality and it was abandoned. There were attempts to recolonise this area with Czechs and emigrants but the number of inhabitants never reached the previous population density (Nikrmajer 2003; Jílek 2005a; Mörtl 2006). From 1948 till 1989 , the border was closed and a border zone $2-6 \mathrm{~km}$ wide with banned entry was established. During this time, more than a hundred municipalities ceased to exist in this area (Jílek 2003; Jílek 2005b; Matušková 2005b; Klobása 2006).

The most important business in the past and recently is forestry and wood production. In the past, wood production was connected to the paper industry and a smaller part to the local production of glass, which now no longer exists (Lněničková 1996; Procházka 2005; Fröhlich and Lněničková 2006). Agriculture in the Šumava region, in terms of income, was never important, however, it provided all the food for the local people, but more common were cattle breeding or fish farming at the lower altitudes (Český les and Novohradské hory). Mechanical engineering plants and raw mineral material processing are also present in this region (Kočárek jun. 2005; Stejskal 2006). From the

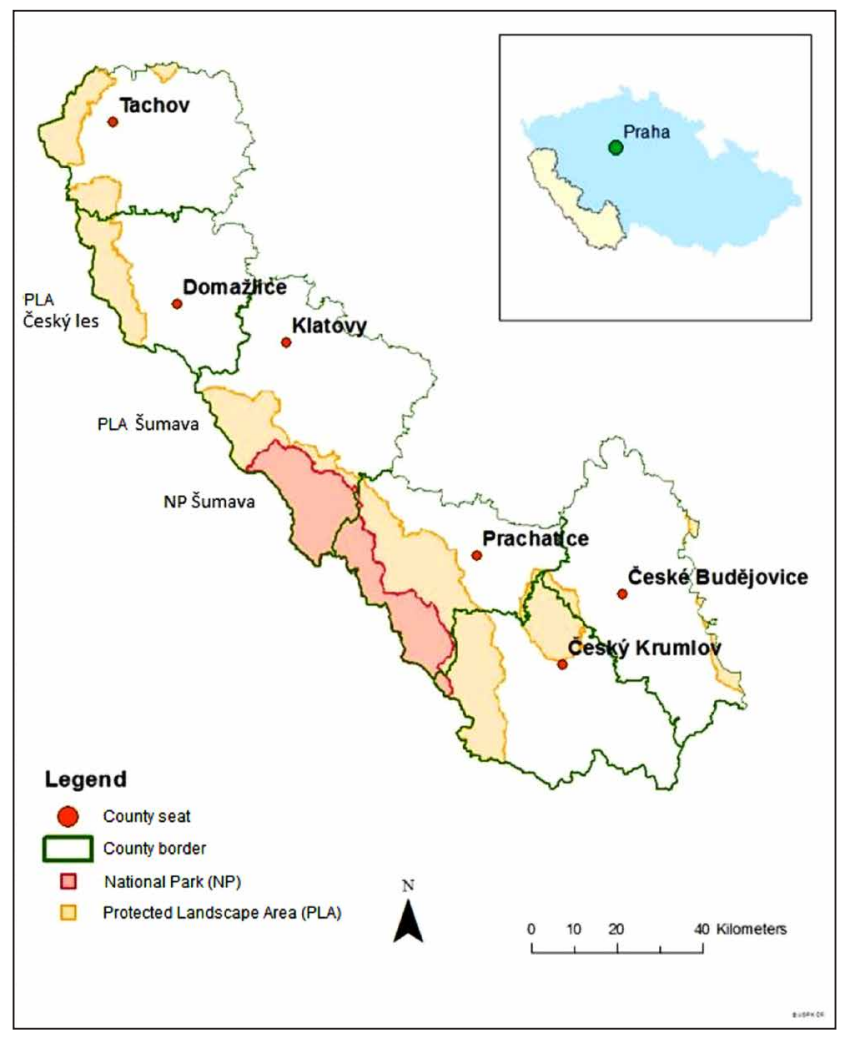

Fig. 1 Map of the south-western border region of the Czech Republic showing the large protected areas: NP - National Park (pink), PLA Protected Landscape Area (orange).

time of the establishment of the NP and PLA, tourism provided the major part of income in this area (Bartoš and Čihař 2011; Dickie and Whiteley 2013).

\section{Municipalities studied}

The municipalities studied were either located in the NP or PLA, or outside these protected areas. The number of inhabitants was taken into account using a method used by the Czech Statistical Institute (CSI) in which municipality size is measured in terms of the number of inhabitants per $\mathrm{km}^{2}$ (CSI 2009; 2013; 2014). This enabled us to select municipalities with very dense populations (e.g. Kubova Hut') and those with high values for the relevant indicators (e.g. Modrava - municipality with a high level of tourism), which resulted in the selection of a total of 39 municipalities (Fig. 2).

Demographic data for the 39 municipalities selected were obtained from the CSI and are for the years 1991 and 2011 when there were censuses of the populations and households in these municipalities. The CSI also provided data on socio-economic factors (years 2003 and 2011) and the information about municipality budgets (years 1994 and 2011) was obtained from the Czech Ministry of Finance. The changes that occurred in land use were obtained from the State Administration of Land Surveying and Cadastre. 


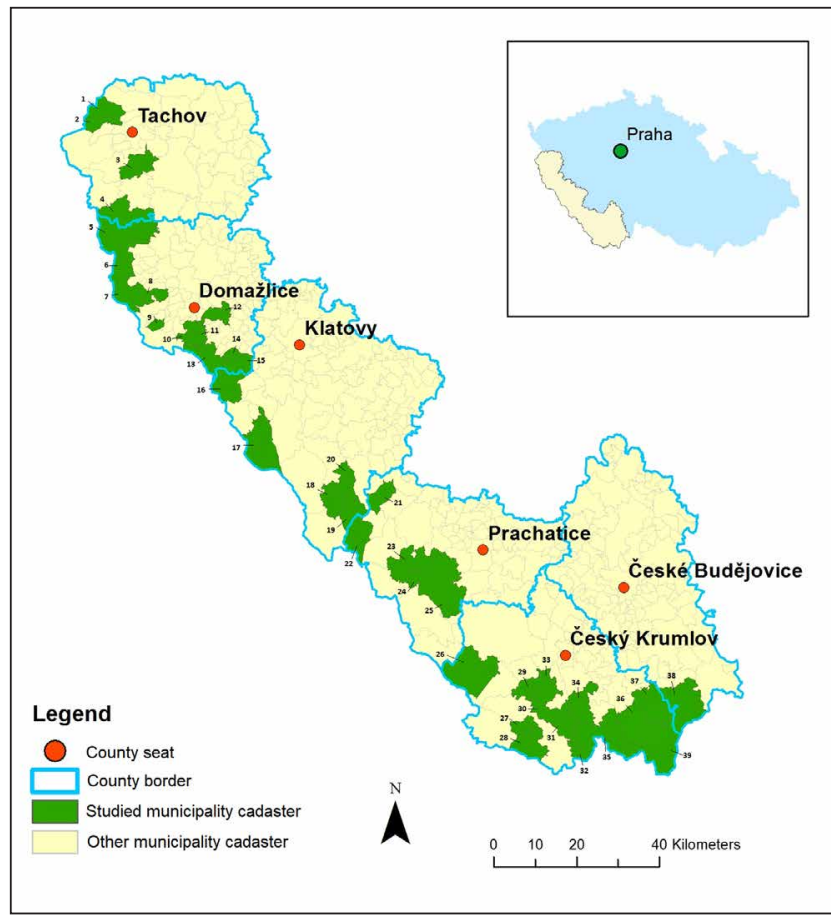

Fig. 2 Cadastral map showing the locations of the municipalities studied (green): 1 - Halže, 2 - Obora, 3 - Staré Sedliště, 4 - Třemešné, 5 - Bělá nad Radbuzou, 6 - Rybník, 7 - Nemanice, 8 - Postřekov, 9 - Pec, 10 - Tlumačov, 11 - Mrákov, 12 - Zahořany, 13 - Všeruby, 14 - Chodská Lhota, 15 - Pocinovice, 16 - Chudenín, 17 - Železná Ruda, 18 - Srní, 19 - Horská Kvilda, 20 - Rejštejn, 21 - Stachy, 22 - Kvilda, 23 - Horní Vltavice, 24 - Lenora, 25 - Volary, 26 - Horní Planá, 27 - Lipno nad Vltavou, 28 - Loučovice, 29 - Světlík, 30 - Malšín, 31 - Rožmberk nad Vltavou, 32 - Horní Dvořiště, 33 - Bohdalovice, 34 - Rožmitál na Šumavě, 35 - Dolní Dvořiště, 36 - Malonty, 37 - Benešov nad Černou, 38 - Horní Stropnice, 39 - Pohorská Ves.

\section{Data analyses}

Statistical analyses were performed using STATISTICA 12 and general linear models. We used ANCOVA to identify changes in the factors selected with number of inhabitants (year 1991) as a covariate, independent variable was type of area $(0$ - outside protected area, 1 - Český les PLA, 2 - Šumava NP and PLA) and dependent variable was the change in the factor over time. We used the Shapiro-Wilk test to determine whether the data was normally distributed before ANCOVA and whether a $\operatorname{logarithmic}$ transformation $\log (\mathrm{x}+1)$ was necessary.

Maps were prepared using ArcGIS 10.4 with map layers from two databases: ArcČR500 and AOPK ČR.

\section{Results}

\section{Demographic indicators}

Total number of inhabitants in the municipalities studied was 31,439 in 1991 and 31,682 in 2011, with a slightly greater decrease in the number of inhabitants in municipalities located in NP or PLA from 11,214 in 1991 to
10,937 in 2011. Number of inhabitants in Český les PLA slightly increased from 4,813 in 1991 to 4,884 in 2011. There was a slight increase in the number of inhabitants in municipalities outside protected areas from 15,412 in 1991 to 15,861 in 2011. ANCOVA revealed a significant effect of municipality size on the change in the number of inhabitants $(\mathrm{p}=0.042)$ and that location inside or outside protected area had no significant effect $(\mathrm{p}=0.905)$.

Level of unemployment increased from $3.244 \%$ in 1991 to $13.047 \%$ in 2011 . The average unemployment in municipalities outside protected areas was $3.438 \%$ in 1991 and $13.702 \%$ in 2011 and inside protected areas $2.679 \%$ in 1991 and $12.282 \%$ in 2011 . Similarly, the ANCOVA results revealed a significant effect of municipality size $(\mathrm{p}=0.002)$ and insignificant effect of location $(p=0.112)$. Regression analysis revealed that there was a higher level of unemployment in municipalities with low numbers of inhabitants.

Percentage of inhabitants of productive age (15-64 years) was $66.141 \%$ in 1991 and $70.359 \%$ in 2011 . The highest increase was recorded in municipalities outside protected areas and the lowest in the Šumava NP and PLA. ANCOVA revealed no significant effect on the percentage of inhabitants of productive age of either of municipality size $(\mathrm{p}=0.088)$ or location $(\mathrm{p}=0.167)$.

ANCOVA of all three above mentioned factors revealed a significant effect of municipality size $(\mathrm{p}=0.001)$, whereas location of the municipality inside or outside a protected area (NP or PLA) has no significant effect on its demographic factors $(\mathrm{p}=0.154)$ (Fig. 3).

\section{Socio-economic indicators}

In the municipalities studied there were 7,068 socio-economic indicators in 2003 and 8,229 in 2011. The increase was obvious both inside and outside protected

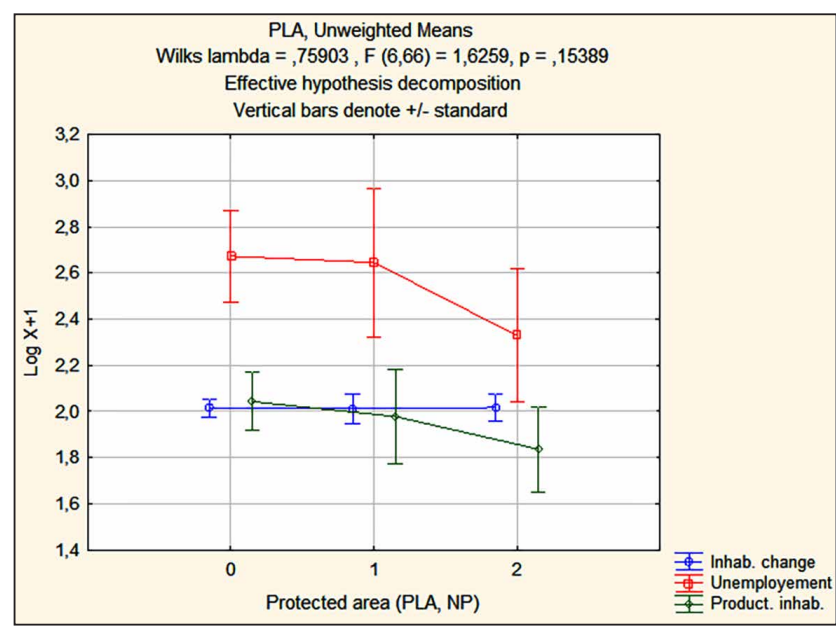

Fig. 3 ANCOVA of the changes in number of inhabitants, level of unemployment and inhabitants of productive age in the years 1991 and 2011. Locality type: 0 - outside protected area, 1 - Český les PLA, 2 - Šumava NP and PLA. 
areas, however, a marginal increase was detected in an area no part of which was ever protected, namely from 2,826 to 3,676 . The lowest number of socio-economic indicators was recorded in the NP and PLA. ANCOVA showed no significant association between municipality size and number of socio-economic indicators $(\mathrm{p}=0.097)$, but municipality location was significantly associated ( $\mathrm{p}<0.001)$ (Fig. 4).

Of the total number of inhabitants more than 15 years old, $2.85 \%$ obtained a university degree in 1991 and $4.61 \%$ in 2011. ANCOVA showed a significant association between municipality size and the percentage obtaining a university degree $(\mathrm{p}=0.022)$, but no significant association with municipality location $(\mathrm{p}=0.908)$. ANCOVA also revealed that the existence of nursery and primary schools is associated with municipality size $(\mathrm{p}<0.001)$ and no significant association between municipality location and nursery schools $(\mathrm{p}=0.338)$ or

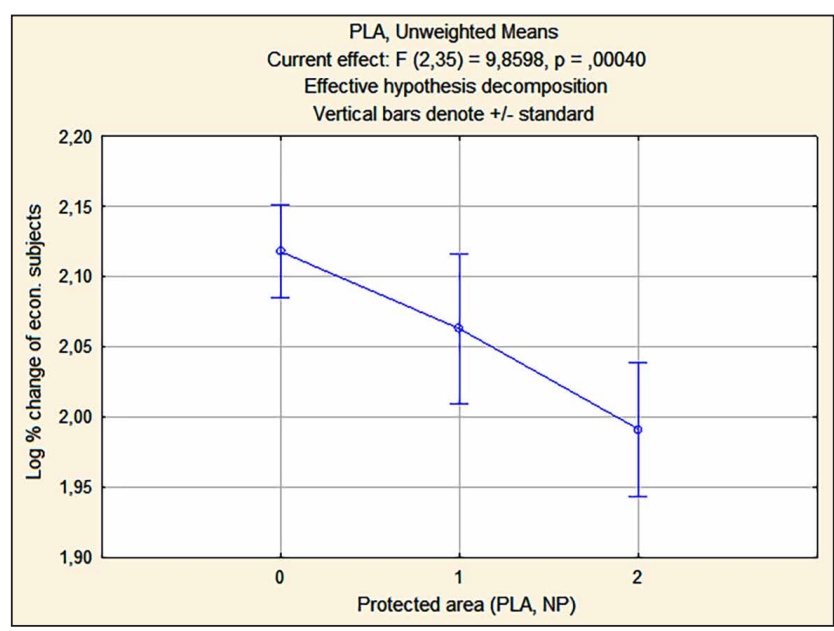

Fig. 4 Results of the ANCOVA of the number of socio-economic indicators in the municipalities studied in 2003 and 2011. Locality type: 0 - outside protected area, 1 - Český les PLA, 2 -Šumava NP and PLA.

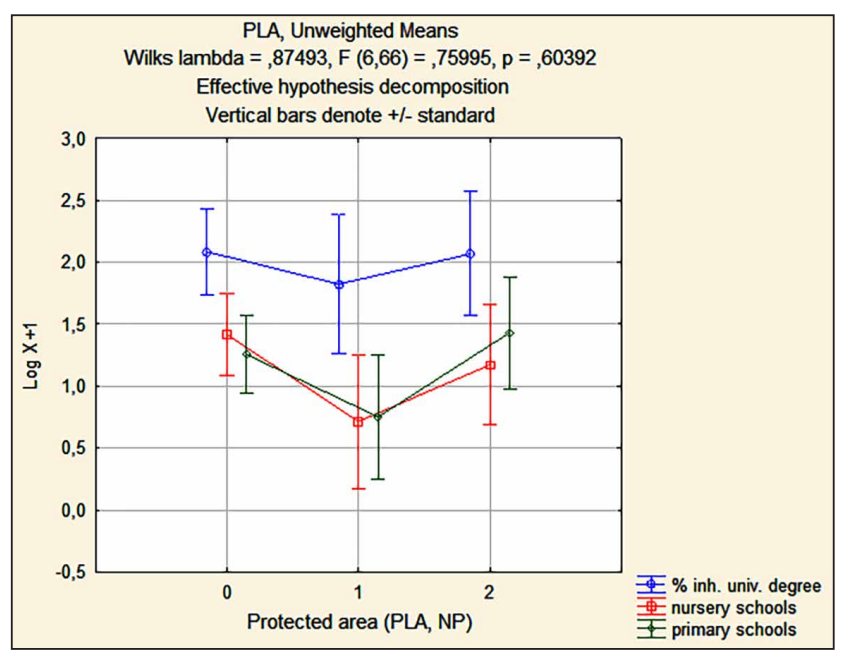

Fig. 5 Results of the ANCOVA of the inhabitants with a university degree and the existence of nursery and primary schools in 1991 and 2011 (in \%). Locality: 0 - outside protected area, 1 - Český les PLA, 2 - Šumava NP and PLA. primary schools $(p=0.444)$. ANCOVA of all socio-economic indicators, except economic entities, indicated statistically significant associations with municipality size $(\mathrm{p}<0.001)$ and no significant association with locality $(\mathrm{p}=0.604)$ (Fig. 5).

\section{Landscape indicators}

The area covered by the municipalities studied was $1,611.361 \mathrm{~km}^{2}$ in 1993 and $1,625.767 \mathrm{~km}^{2}$ in 2011 . The marginal increase in the area covered by the municipality Srní, from $21.823 \mathrm{~km}^{2}$ to $33.485 \mathrm{~km}^{2}$ was due to the closure of the military training area Dobrá Voda. Changes in the areas covered by the other municipalities did not exceed $3 \mathrm{~km}^{2}$.

Number of new houses increased from 7,348 in 1991 to 9,589 in 2011. Most (61\%) of these houses were built in localities situated outside protected areas. The highest increase in the number of houses was recorded in the smallest municipalities in 1991. ANCOVA revealed a significant association between municipality size and the increase in the number of houses $(\mathrm{p}=0.011)$ and insignificant association with the localities of the municipalities $(p=0.162)$. We also tested the changes in the numbers of unoccupied houses but they were not significantly associated with either municipality size $(\mathrm{p}=0.501)$ or location ( $p=0.270)$. Similarly, there were no significant associations of changes in terms of recreation (municipality size: $\mathrm{p}=0.163$; municipality location: $\mathrm{p}=0.624$ ).

ANCOVA revealed significant associations between municipality size $(p=0.022)$ and location $(p=0.011)$, and changes in land use (arable land, forest, grasslands, built-up area). In particular, changes in the area of arable land (municipality size: $\mathrm{p}=0.001$; municipality location: $p=0.003$ ) with the highest decrease occurring in the Šumava NP and PLA, changes in the extent of forest (municipality size: $\mathrm{p}=0.647$; municipality location: $\mathrm{p}=0.954$ ), grassland (municipality size: $\mathrm{p}=0.784$; municipality location: $\mathrm{p}=0.157$ ) and built-up areas (municipality size: $\mathrm{p}=0.228$; municipality location: $\mathrm{p}=0.903$ ). ANCOVA summary revealed a significant association of landscape indicators with municipality size $(\mathrm{p}=0.028)$ and insignificant association with municipality location $(\mathrm{p}=0.077)$ (Fig. 6).

\section{Income indicators}

Municipality income in the area studied was 312.141 thousand CZK (Czech crowns) in 1994 and 722.577 thousand CZK in 2011. ANCOVA revealed a significant association between municipality size and income $(p=0.033)$, but no association with municipality location $(\mathrm{p}=0.061)$. Average income per inhabitant increased from 9,948 CZK in 1994 to 27,167 CZK in 2011. ANCOVA revealed a significant association between the locality of the municipali- 


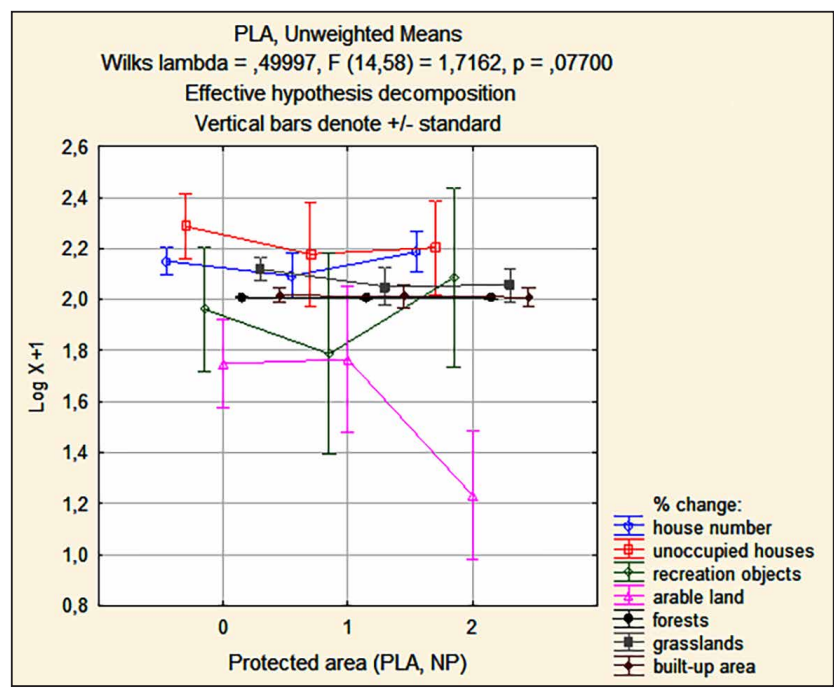

Fig. 6 Results of the ANCOVA of the changes in landscape indicators in 1991 (number of houses), 1993 (type of land use) and 2011 (\% change in the number of houses unoccupied houses, recreation objects, arable land, forest, grasslands, built-up area; Locality: 0 - outside protected area, 1 - Český les PLA, 2 - Šumava NP and PLA.

ties and income $(\mathrm{p}=0.053)$ and an insignificant association with the size of the municipalities $(\mathrm{p}=0.143)$. The greatest increase was recorded in municipalities located in the Český les PLA. ANCOVA summary showed a significant association with municipality size $(\mathrm{p}=0.021)$ and insignificant association with municipality location $(\mathrm{p}=0.199)$ (Fig. 7). Figures 8 and 9 show incomes per inhabitant.

\section{Discussion}

Demography of the population in south-western border of the Czech Republic was affected by recent political changes, particularly in the second half of the 20th century when a restricted border zone several kilometres wide was created. This resulted in ecosystems almost unaffected by human activities, which were worth preserving as protected areas (Bláha et al. 2013; Křenová and Vrba 2014). National Park Šumava was established in 1991 (Protected Landscape Area Šumava existed from 1963) and the Protected Landscape Area Český les in 2005. The existence of these protected landscapes and the national park limited their socio-economic development. This comparative study attempts to evaluate in terms of demography, economy and landscape use the effect on municipalities of being inside such protected areas.

This study is unique in considering a large number of factors over a long period of time. Most of the recent literature focuses on one factor, for example, effect of tourism on the economy of the area (Bodnár 2006; Cottrell and Raadik 2008; Mayer et al. 2010). Some of them only consider the effects within protected areas and do not compare it with what is happening in surrounding areas (Dickie and Whiteley 2013). Many papers deal with the

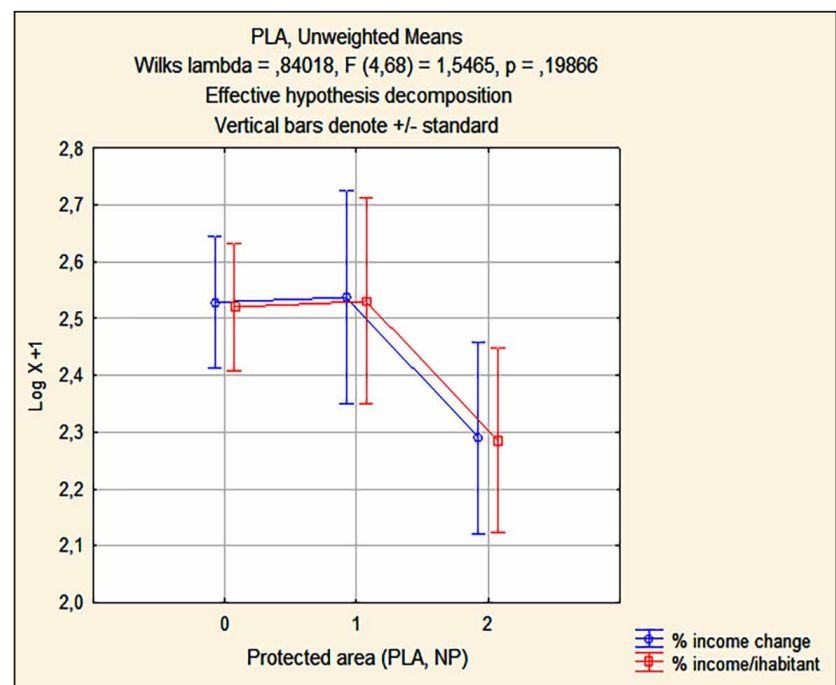

Fig. 7 Results of the ANCOVA of the changes in the incomes per inhabitant in 1994 and 2011, in terms of \% income/percentage change in income, \% income/inhabitant; Locality: 0 - outside protected area, 1 - Český les PLA, 2 - Šumava NP and PLA.

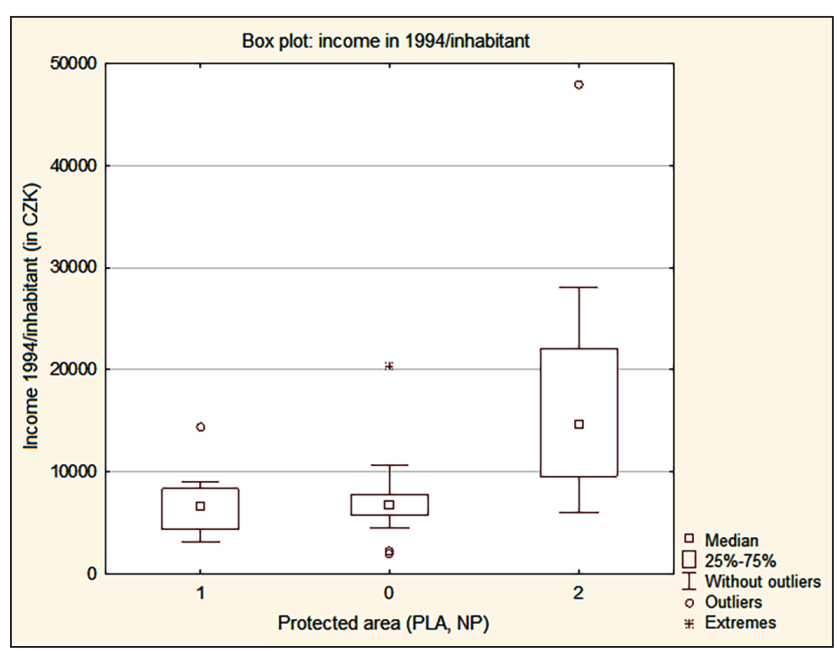

Fig. 8 Box plot showing the income per inhabitant in the different municipalities in 1994. Locality: 0 - outside protected area, 1 - Český les PLA, 2 - Šumava NP and PLA.

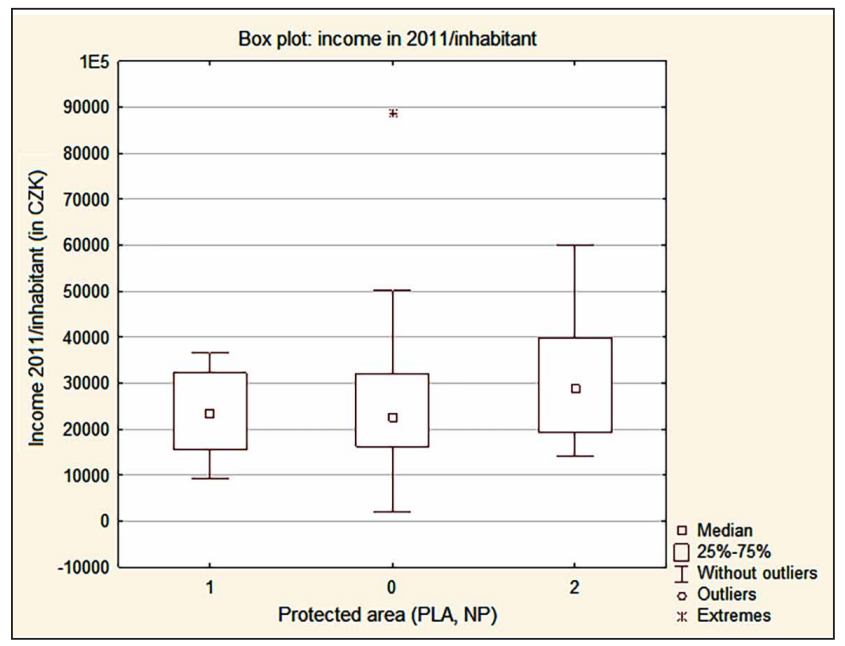

Fig. 9 Box plot showing the income per inhabitant in in the different municipalities in 2011. Locality: 0 - outside protected area, 1 - Český les PLA, 2 - Šumava NP and PLA. 
Table 1 Descriptive statistics of demographic indicators.

\begin{tabular}{|l|c|c|c|c|c|}
\hline \multirow{2}{*}{\multicolumn{1}{|c|}{ Variable }} & \multicolumn{5}{c|}{ Descriptive statistics } \\
\cline { 2 - 6 } & Valid N & Average & Minimum & Maximum & Stand. Dev. \\
\hline \% unemployment 1991 & 39 & 0.03 & 0.00 & 0.12 & 0.02 \\
\hline Number of inhabitants 1991 & 39 & 806.13 & 27.00 & $3,917.00$ & 761.61 \\
\hline Number of inhabitants 2011 & 39 & 812.36 & 72.00 & $3,744.00$ & 741.68 \\
\hline Change of inhabitants & 39 & 105.11 & 71.22 & 266.67 & 30.14 \\
\hline \% unemployment 2011 & 39 & 0.13 & 0.04 & 0.39 & 0.07 \\
\hline Change of unemployment & 39 & 548.31 & 0.00 & $2,658.88$ & 473.03 \\
\hline \% inhab. in product. age 1991 (15-64) & 39 & 0.67 & 0.59 & 0.75 & 0.04 \\
\hline \% inhab. in product. age 2011 (15-64) & 39 & 0.70 & 0.45 & 0.76 & 0.05 \\
\hline Change of inhabitants in product. age & 39 & 125.17 & 15.83 & 950.00 & 150.96 \\
\hline
\end{tabular}

Table 2 Descriptive statistics of socio-economic indicators.

\begin{tabular}{|l|c|c|c|c|c|}
\hline \multirow{2}{*}{\multicolumn{1}{|c|}{ Variable }} & \multicolumn{5}{c|}{ Descriptive statistics } \\
\cline { 2 - 6 } & Valid N & Average & Minimum & Maximum & Stand. Dev. \\
\hline \% inhabitants with univ. degree 1991 & 39 & 0.02 & 0.00 & 0.05 & 0.01 \\
\hline \% inhabitants with univ. degree 2011 & 39 & 0.05 & 0.19 & 0.19 & 0.03 \\
\hline Change of inhabitants with univ. degree & 39 & 209.84 & 0.00 & 633.64 & 149.06 \\
\hline Number of economical subjects 2003 & 39 & 181.23 & 35.00 & 885.00 & 192.85 \\
\hline Number of economical subjects 2011 & 39 & 211.00 & 34.00 & 976.00 & 212.19 \\
\hline Change of economical subjects & 39 & 120.17 & 53.97 & 190.08 & 24.86 \\
\hline Number of nursery schools 1991 & 39 & 0.87 & 0.00 & 2.00 & 0.52 \\
\hline Number of nursery schools 2011 & 39 & 0.67 & 0.00 & 1.00 & 0.48 \\
\hline \% of nursery school persistence & 39 & 57.69 & 0.00 & 100.00 & 48.04 \\
\hline Number of primary schools 1991 & 39 & 0.78 & 0.00 & 1.00 & 0.46 \\
\hline Number of primary schools 2011 & 39 & 0.64 & 0.00 & 2.00 & 0.58 \\
\hline \% of primary school persistence & 39 & 64.10 & 0.00 & 200.00 & 58.43 \\
\hline
\end{tabular}

Table 3 Descriptive statistics of landscape use indicators.

\begin{tabular}{|l|c|c|c|c|c|}
\hline \multirow{2}{*}{ Variable } & \multicolumn{5}{c|}{ Descriptive statistics } \\
\cline { 2 - 6 } & Valid N & Average & Minimum & Maximum & Stand. Dev. \\
\hline Number of houses 1991 & 39 & 188.41 & 13.00 & 503.00 & 136.38 \\
\hline Number of houses 2011 & 39 & 245.87 & 30.00 & 624.00 & 167.18 \\
\hline \% change in house number & 39 & 148.35 & 110.48 & 443.86 & 69.14 \\
\hline \% abandoned houses 1991 & 39 & 0.20 & 0.02 & 0.89 & 0.15 \\
\hline \% abandoned houses 2011 & 39 & 0.31 & 0.10 & 0.63 & 0.13 \\
\hline \% change in abandoned houses & 39 & 244.49 & 70.44 & $1,900.00$ & 351.08 \\
\hline \% of recreation houses 1991 & 39 & 0.56 & 0.00 & 1.00 & 0.28 \\
\hline \% of recreation houses 2011 & 39 & 0.63 & 0.11 & 0.96 & 0.20 \\
\hline \% change in recreation houses & 39 & 150.86 & 0.00 & $1,463.42$ & 225.94 \\
\hline \% arable land 1993 & 39 & 0.18 & 0.00 & 0.48 & 0.14 \\
\hline \% arable land 2011 & 39 & 0.13 & 0.00 & 0.44 & 0.13 \\
\hline \% change in arable land & 39 & 58.84 & 0.00 & 122.70 & 35.14 \\
\hline \% forests 1993 & 39 & 0.54 & 0.19 & 0.88 & 0.18 \\
\hline \% forests 2011 & 39 & 0.54 & 0.19 & 0.88 & 0.18 \\
\hline \% change in forests & 39 & 101.07 & 94.42 & 105.05 & 1.97 \\
\hline \% permanent grasslands 1993 & 39 & 0.18 & 0.05 & 0.28 & 0.06 \\
\hline \% permanent grasslands 2011 & 39 & 0.23 & 0.05 & 0.49 & 0.10 \\
\hline \% change in permanent grasslands & 39 & 125.35 & 71.12 & 201.72 & 30.78 \\
\hline
\end{tabular}

European Journal of Environmental Sciences, Vol. 9, №. 2 


\begin{tabular}{|l|r|r|r|r|r|r|}
\hline \% built-up area 1993 & 39 & 0.01 & 0.00 & 0.01 & 0.00 \\
\hline \% built-up area 2011 & 39 & 0.01 & 0.00 & 0.01 & 0.00 \\
\hline \% change in built-up area & 39 & 103.36 & 73.15 & 173.16 & 15.41 \\
\hline
\end{tabular}

Table 4 Descriptive statistics of municipality incomes.

\begin{tabular}{|l|c|c|c|c|c|}
\hline \multirow{2}{*}{\multicolumn{1}{|c|}{ Variable }} & \multicolumn{4}{c|}{ Descriptive statistics } \\
\cline { 2 - 6 } & Valid N & Average & Minimum & Maximum & Stand. Dev. \\
\hline Municipality income 1994 & 39 & $8,003.62$ & 458.82 & $50,553.04$ & $11,745.47$ \\
\hline Municipality income 2011 & 39 & $18,527.62$ & $2,156.00$ & $72,716.00$ & $17,421.20$ \\
\hline Change in municipality income & 39 & 350.51 & 33.70 & 778.88 & 188.02 \\
\hline Municipality income/inhabitant 1994 & 39 & $9,948.14$ & $1,954.09$ & $47,972.42$ & $8,456.95$ \\
\hline Municipality income/inhabitant 2011 & 39 & $27,166.69$ & $2,013.87$ & $88,715.76$ & $16,295.62$ \\
\hline Change in municipality income/inhabit. & 39 & 337.29 & 33.59 & 757.80 & 171.61 \\
\hline
\end{tabular}

same area in the Czech Republic (Hampl 2005; Havlícek et al. 2005), however, none of them compare the effects in protected areas with those in unprotected areas that are similar in terms of natural conditions and history. Although large protected areas have been studied as a whole (NSW department of environment and conservation, 2006) these studies are based mostly on questionnaires, depict the current situation and do not evaluate the changes that might have occurred over time (Bartoš and Čihař 2011).

In contrast to the above, we used a large data set, which included records of demographic, socio-economic, landscape use and municipality income indicators for the years 1991 and 2011. The results indicate that almost every indicator was significantly associated with municipality size, but not with whether they were located within or outside a protected zone. For example, unemployment is $1.5 \%$ lower in municipalities located in protected areas than outside such areas. This indicates that jobs are available in national parks and protected landscape areas even though some only seasonal jobs (Picek et al. 2007). Holmes and Hecox (2004) and Job (2008) state that in the areas they studied the level of unemployment decreases with increase in the percentage of wilderness.

Moreover, there was an insignificant association between whether the municipalities were within or without protected areas and the numbers of inhabitants of productive age (15-64 years) as previously reported by Galland (2011) and Perlín and Bičík (2010). The long-term study in the Greater Shoalhaven region in New South Wales (Australia) indicates that the population almost doubled after it was designated a national park and unemployment decreased from $14.9 \%$ to $9.0 \%$ (NSW department of environment and conservation, 2006). This region is not comparable in terms of the natural conditions with the Czech Republic, but this study does indicate the benefits in terms of demography and socio-economics of being located within a protected area (Carrol and Phillipson 2002; Defra 2011).
In the case of the Šumava NP, the situation might differ because many of the inhabitants have permanent residences elsewhere in the Czech Republic and their income is not included in the budget of the municipality where they operate their business (Dickie and Whiteley 2013). Thus, it is difficult for the local inhabitants to appreciate the benefits of being in a protected area when the income from tourism goes elsewhere (Richardson 2009; Bartoš and Čihař 2011). There are, however, examples of local people appreciating the economic benefits of being in a protected area as in the Biospheric Reserve Etlebuch (Wallner et al. 2007). Similarly, the nearby Bavarian Forest NP profits from nature protection as it has a positive effect on the local population and economy (Job et al. 2004a,b, 2005; Job 2008). According to Thompson and Peepre (2011) and Carrol and Phillipson (2002), only a few extra jobs are necessary for it to have a positive effect on the local economy.

\section{Conclusion}

The aim of this study was to determine the effect on the socio-economic development of municipalities within protected areas, which are constrained by the need to protect nature. This was done by comparing similar municipalities inside and outside protected areas over a period of 20 years (1991-2011). The18 indicators measured in the 39 municipalities studied did not differ significantly in 1991. Two decades later there were significant differences in the demography, economy and landscape usage, however, this was not associated with being located in a protected area but with the size of the municipalities. Similarly, in the above-cited publications of studies in other countries and regions, municipalities located within protected areas profit from it or it has more positive effects on their socio-economic indicators than negative effects. There is an urgent need to greatly improve the communication between local people, local offices and the authorities in protected areas. 


\section{Acknowledgements}

This research was supported by the MSMT within the National Sustainability Program I (NPU I), grant number LO1415.

\section{REFERENCES}

Albrecht J et al. (2003) Českobudějovicko. In: Mackovčin P, Sedláček M (eds) Chráněná území ČR, svazek VIII. Agentura ochrany prírody a krajiny ČR a EkoCentrum Brno, Praha.

Bartoš L, Čihař M (2011) Socio Environmental Attitudes amongst the Inhabitants of Border Mountain Regions Close to the Former Iron Curtain: The Situation in the Czech Republic. J Environ Prot 2: 609-619.

Bílá K, Hostýnek J, Kindlmann P (2018) Comparison of precipitation and temperature regime in the Šumava National Park and in the surrounding foothills. Eur J Environ Sci 8: 39-46.

Bláha J, Romportl D, Křenová Z (2013) Can Natura 2000 mapping be used to zone the Šumava National Park? Eur J Environ Sci 3: $57-64$.

Bodnár R (2006) Economic and Social Effects of the Development of Recreation and Environmentally Sound Tourism through the Example of a Hungarian National Park. Explor Nature Manag 3: 383-384.

Carrol T, Phillipson J (2002) Sustaining living uplands: The role of the Northumberland national park authority in rural development, research report. University of Newcastle upon Tyne.

Cottrell SP, Raadik J (2008) Socio-Cultural Benefits of Pan Parks: Case Study at Bieszscady National Park. Matkailututkimus 1: 56-67.

Czech Statistical Institute (CSI), Krajská správa České Budějovice, Oddělení regionálních analýz a informačních služeb (2009) Postavení venkova v Jihočeském kraji. Český statistický úřad, České Budějovice 2009. ISBN: 978-80-250-1935-1.

Czech Statistical Institute (CSI) (2013) Sčítání lidu, domů a bytů Pramenné dílo - 2011. czso.cz. [online]. [cit. 2016-05-15]. https://www.czso.cz/csu/czso/24000-13-n_2013-02

Czech Statistical Institute (CSI) (2014) Česká republika od roku 1989 v ćíslech. czso.cz. [online]. [cit. 2016-05-15]. https://www .czso.cz/csu/czso/ceska-republika-od-roku-1989-v-cislech\#01

Defra (2011) National Park Authorities: Assessment of Benefits working paper. Department for Environment, Food and Rural Affairs.

Dickie I, Whiteley G (2013) Economic Assessment of Šumava National Park, final report. Eftec.

Fröhlich J, Lněničková J (2006) Sklářství. In: Dudák V (ed) Novohradské hory a Novohradské podhůř́i - příroda, historie, život. Praha. Baset: 727-734.

Galland P (2011) Sumava National Park (Czech Republic) Application Expert report. Directorate of Culture and Cultural and Natural Heritage.

Hampl M (2005) Geografická organizace společnosti v České republice: transformační procesy a jejich obecný kontext. Praha. PřF UK, DemoArt.

Havlíček T, Jančák V, Chromý P, Marada M (2005) Vybrané teoretickometodologické aspekty a trendy geografického výzkumu periferních oblastí. In: Novotná M (ed) Problémy periferních oblastí, Praha, KSGRR PřF UK.

Holmes FP, Hecox WE (2004) Does wilderness impoverish rural regions? Int J Wilderness 10: 34-39.
Jílek T (2003) Šumava v podmínkách studené války. In: Anděra $\mathrm{M}$ et al. (eds) Šumava - př́roda, historie, život. Praha. Baset: $397-402$.

Jílek T (2005a) Od vzniku republiky do podepsání Mnichovské dohody. In: Dudák V (ed) Český les - př́roda, historie, život. Praha. Baset: 381-384.

Jílek T (2005b) Od roku 1945 do roku 1989. In: Dudák V (ed) Český les - př́roda, historie, život. Praha. Baset: 389-394.

Job H (ed) (2008) The regional economic impact of Bavarian Forest National Park. Bavarian Forest National Park Authority. Grafenau.

Job H, Harrer B, Metzler D, Hajizadeh-Alamdary D (2005) Ökonomische Effekte von Großschutzgebieten. Untersuchung der Bedeutung von Großschutzgebieten für den Tourismus und die wirtschaftliche Ent-wicklung der Region. BfN-Skripten Selbstverlag. Bonn-Bad Godesberg.

Job H, Metzler D, Hajizadeh-Alamdary D, Rodrian P, Woltering M (2004b) Regional Economic Impacts of Sustainable Tourism in Protected Areas. In: Rulle M (ed) Recent Trends in Tourism - the Baltic and the World (= Greifswalder Beiträge zur Regional-, Frei-zeit- und Tourismusforschung 15). Greifswald, pp 141-156.

Job H, Metzler D, Müller M, Mayer M (2004a) The contribution of small and medium tourism enterprises to regional economic development - a comparison be-tween two German national park regions. In: Keller P, Bieger T (eds) The future of small and medium sized enterprises in tourism. 54th Congress 2004 of the International Association of Scientific Experts in Tourism. St. Gallen, pp 55-75.

Klobása P (2006) Zaniklá sídla. In: Dudák V (ed) Novohradské hory a Novohradské podhůř́ - prríroda, historie, život. Praha. Baset: 321-324.

Kočárek E jun (2005) Rybníkářství. In: Dudák V (ed) Český les príroda, historie, život. Praha. Baset: 689-696.

Křenová Z, Vrba J (2014) Just how many obstacles are there to creating a National Park? A case study from the Šumava National Park. Eur J Environ Sci 4: 30-36.

Křivancová S, Vavruška F, Tolasz R (2006) Podnebí. In: Dudák V (ed) Novohradské hory a Novohradské podhůří - příroda, historie, život. Praha. Baset: 89-95.

Lněničková J (1996): Šumavské sklářství. Sušice. Dr. Radovan Rebstöck.

Matušková A (2005a) Obyvatelstvo. In: Dudák V (ed) Český les prŕroda, historie, život. Praha. Baset: 269-272.

Matušková A (2005b) Zaniklé obce a osady. In: Dudák V (ed) Český les - př́roda, historie, život. Praha. Baset: 333-340.

Mayer M, Müller M, Woltering M, Arnegger J, Job H (2010) The economic impact of tourism in six German national parks. Landscape Urban Plan 97: 73-82.

Mörtl P (2006) Reemigrace po roce 1945. In: Dudák V (ed) Novohradské hory a Novohradské podhưř́ - příroda, historie, život. Praha, Baset: 423-428.

Nikrmajer L (2003) Šumava od poloviny 18. století do roku 1938. In: Anděra $\mathrm{M}$ et al. (eds) Šumava - př́roda, historie, život. Praha. Baset: 379-386.

NSW department of environment and conservation (2006) The economic impact of protected areas on the Greater Shoalhaven region, final report.

Perlín R (1998) Typologie českého venkova. Zemědělská ekonomika. 44: 349-358.

Perlín R, Bičík I (2010) Lokální rozvoj na Šumavě. Závěrečná publikace shrnující výsledky projektu Analýza vývoje Národního parku Šumava za období uplynulých 15 let. Správa NP a CHKO Šumava. 
Picek M, Růžička T, Silovský V, Těšitel J, Vlášková K (2007) Cestovní ruch na Šumavě, Rozvojový koncept udržitelného cestovního ruchu, akční program 2. aktualizace. Regionální rozvojová agentura Šumava.

Procházka Z (2005) Sklářství. In: Dudák V (ed) Český les - příroda, historie, život. Praha: Baset: 711-716.

Richardson S (2009) Undergraduates' perceptions of tourism and hospitality as a career choice. Int J Hosp Manag 28: 382-388.

Řezníčková Z (2003) Osídlení Šumavy. In: Anděra M et al. (eds) Šumava - př́roda, historie, život. Praha. Baset: 355-358.

Řezníčková Z (2005) Vývoj osídlení. In: Dudák V (ed) Český les príroda, historie, život. Praha. Baset: 265-268.

Řezníčková Z (2006) Stručný přehled vývoje osídlení. In: Dudák V (ed) Novohradské hory a Novohradské podhůří - příroda, historie, život. Praha. Baset: 279-282.
Sassmann A (2006) Tři sondy do národnostního vývoje. In: Dudák V (ed) Novohradské hory a Novohradské podhưří - příroda, historie, život. Praha: Baset: 337-340.

Sofron J (1990) Přirozená a polopřirozená rostlinná společenstva Českého lesa. - Studie ČSAV. Praha. 17.

Stejskal A (2006) Počátky a rozvoj rybníkářství. In: Dudák V (ed) Novohradské hory a Novohradské podhůří - př́roda, historie, život. Praha. Baset: 701-704.

Thompson J, Peepre J (2011) Economic benefits of protected areas. Canadian Parks and Wilderness Society.

Wallner A, Bauer N, Hunziker M (2007) Evaluations of Biosphere Reserves by Local Residents in Switzerland and Ukraine. Landscape Urban Plan 83: 104-114.

Zahradnický J, Mackovčin P (eds) (2004) Plzeňsko a Karlovarsko. In: Mackovčin P, Sedláček M (eds) Chráněná území ČR, svazek XI. Agentura ochrany prírody a krajiny ČR a EkoCentrum Brno, Praha. 